\title{
Quantified Distribution of the Noradrenaline Innervation in the Hippocampus of Adult Rat
}

\author{
Sharon Oleskevich, Laurent Descarries, and Jean-Claude Lacaille \\ Centre de recherche en sciences neurologiques (Départment de physiologie), Faculté de médecine, Université de \\ Montréal, Montréal, Québec, Canada H3C 3J7
}

\begin{abstract}
A recently developed radioautographic technique, based on the uptake labeling of monoamine terminals (axonal varicosities) in vitro, was used to quantify the noradrenaline (NA) innervation in adult rat hippocampus. After incubation of brain slices with $1 \mu \mathrm{M}$ 'H-NA, the NA varicosities were visualized as small aggregates of silver grains, in light microscope radioautographs prepared at 3 equidistant horizontal levels across the ventral $2 / 3$ of the hippocampus. Using a computer-assisted image analyzer, counts were obtained from the subiculum (SUB), 3 sectors of Ammon's horn (CA1, CA3-a, CA3-b) and 3 sectors of the dentate gyrus (DG-medial blade, crest, and lateral blade), every lamina being sampled in each region. After a double correction for duration of radioautographic exposure and section thickness, and following measurement of varicosity diameter in electron microscope radioautographs, it was possible to express these results in number of terminals per volumetric unit of tissue. It was thus found that the overall density of hippocampal NA innervation averages 2.1 million varicosities $/ \mathrm{mm}^{3}$ of tissue, a value almost twice as high as that in cerebral cortex. This innervation is $20 \%$ denser ventrally than dorsally and is heterogeneous both in terms of regional and laminar distribution. SUB and DG are more strongly innervated than Ammon's horn, whereln CA1 has the lowest overall density. In SUB and CA1, there is a clear predilection of NA varicosities for the stratum moleculare. In CA3, there is a narrow band of even stronger innervation in the stratum radiatum, near the apical border of the stratum pyramidale, contrasting with a 3 times lower density in this cell layer and the stratum oriens. In DG, the NA innervation is again the weakest in the cell body layer (granule) and exhibits an almost 3-fold greater density in the polymorph layer, the highest of all hippocampus. These figures allow for numerous correlations with other quantitative parameters-cytological, biochemical, and pharmacological-of NA function in the hippocampus. They also provide a strong basis for elucidating, at a cellular level, the action of NA in this part of the brain.
\end{abstract}

\footnotetext{
Received Dec. 8, 1988; revised Feb. 27, 1989; accepted Mar. 14, 1989

This research was supported by FCAR and FRSQ studentships to S.O., grant MT-3544 from the Medical Research Council of Canada to L.D., and a Subvention d'équipe pluridisciplinaire (Equipe de recherche sur les neurotransmetteurs du cerveau) from the FRSQ. J.-C.L. holds a Scholarship from the FRSQ and is a Sloan Research Fellow. We are also grateful to Sylvia Garcia and Kenneth $\mathrm{C}$. Watkins for technical assistance and to Giovanni Battista Filosi and Daniel Cyr for graphic and photographic work.

Correspondence should be addressed to Laurent Descarries, M.D., Département de physiologie, Université de Montréal, CP 6128, Succursale A, Montréal, Québec, Canada H3C $3 \mathrm{~J} 7$.
}

Copyright (C) 1989 Society for Neuroscience $0270-6474 / 89 / 113803-13 \$ 02.00 / 0$
As demonstrated by catecholamine-fluorescence histochemistry and dopamine- $\beta$-hydroxylase immunohistochemistry, the hippocampal formation receives a relatively dense noradrenaline (NA) innervation in adult rat (Fuxe, 1965; Blackstad et al., 1967; Lindvall and Björklund, 1974; Moore, 1975; Swanson and Hartman, 1975; Hökfelt et al., 1976; Loy et al., 1980). The distribution of this input has been further documented by regional measurements of the high-affinity uptake of ${ }^{3} \mathrm{H}-\mathrm{NA}$ (StormMathisen and Guldberg, 1974) or microdeterminations of the hippocampal NA content under diverse experimental conditions (Moore, 1975; Gage et al., 1978, 1983; Loy et al., 1980; Haring and Davis, 1985). Radioautographic tracing studies after axonal transport of radiolabeled proteins (Jones and Moore, 1977) and retrograde labeling studies with HRP or fluorescent dyes (Loy et al., 1980; Room et al., 1981; Haring and Davis, 1983,1985 ) have indicated that the NA input to rat hippocampus arises entirely from the nucleus locus coeruleus $(A-6)$ and reaches its destination via 3 main pathways: the fimbria-fornix, the fasciculus cinguli, and the ventral amygdaloid bundle. The functional properties and role of this afferent system have received considerable attention (for reviews, see Foote et al., 1983, and Saper, 1987).

At a cellular level, 4 subtypes of adrenoceptors have been identified and localized in the hippocampus: alpha-1 (Young and Kuhar, 1980; Tayrien and Loy, 1984; Jones et al., 1985; Goffinet and Caviness, 1986), alpha-2 (Unnerstall et al., 1984; Bruning et al., 1987), beta-1, and beta-2 (Rainbow et al., 1984; Lorton and Davis, 1987). Although initially believed to serve mainly as an inhibitory transmitter in this part of the CNS (Herrling, 1981; Segal, 1981; Langmoen et al., 1981), hippocampal NA is now known to exert diverse effects on Ammon's horn or dentate gyrus (DG) neurons (Madison and Nicoll, 1982, 1988; Neuman and Harley, 1983; Sah et al., 1985; Lancastcr and Adams, 1986; Gray and Johnston, 1987; Pang and Rose, 1987; Hopkins and Johnston, 1988; Lacaille and Schwartzkroin, 1988c). In the face of this detailed information, and despite increasing use of the hippocampal slice as a tool for investigating NA actions in CNS, truly quantitative data on the topographical features of the hippocampal NA innervation are still lacking. In this context, we have applied to the hippocampus a recently developed radioautographic approach that allows for the counting of the various types of monoamine axonal varicosities (terminals) after their uptake labeling in rat cerebral hemisphere slices incubated with the respective tritiated amines (Doucet et al., 1988). In this paper, we report on the regional and laminar density of the NA innervation at 3 horizontal levels across 7 hippocampal sectors representing every major subdivision of adult rat hippocampus. A similar description is forthcoming of 
the 5-HT innervation (S. Oleskevich and L. Descarrics, unpublished observations).

\section{Materials and Methods}

Uptake labeling and radioautography. Adult male Sprague-Dawley rats (body weight, $250 \pm 20 \mathrm{gm}$ ) were anesthetized with pentobarbital and perfused for 3-5 min, via the aortic arch, with 500-600 ml ice-cold artificial cerebrospinal fluid (CSF) containing $1 \%$ dextrose and freshly gassed with carbogen $\left(95 \% \mathrm{O}_{2}\right.$ and $\left.5 \% \mathrm{CO}_{2}, \mathrm{pH} 7.4\right)$. A thick (3-5 mm) horizontal slab comprising the hippocampus was excised from the caudal half of one cerebral hemisphere and cut in serial $200-\mu \mathrm{m}$-thick slices using a Vibratome filled with melting CSF ice. Slices closest to horizontal stereotaxic planes $\mathrm{H} 2.9 \mathrm{~mm}, 3.9 \mathrm{~mm}$, and $4.9 \mathrm{~mm}$ (interaural) were selected for incubation.

Within $60 \mathrm{~min}$ of the perfusion, the slices were set to preincubate for $15 \mathrm{~min}$ at $35^{\circ} \mathrm{C}$, under carbogen atmosphere, in $2-3 \mathrm{ml}(1 \mathrm{ml} / \mathrm{slice})$ of CSF containing $0.1 \mathrm{~mm}$ of the monoamine oxidase inhibitor, pargyline hydrochloride (Aldrich).

The period of incubation proper was initiated by addition of $1 \mu \mathrm{M}$ ${ }^{3} \mathrm{H}-\mathrm{NA}$ (New England Nuclear, $43.7 \mathrm{Ci} / \mathrm{mm}$ ) concentrated in a small volume of CSF containing $4 \%$ ascorbic acid. Incubation lasted $15 \mathrm{~min}$ and was terminated by replacing the medium with fixative. Aliquots were saved for measurements of radioactivity by liquid scintillation counting.

In all, 7 experiments were carried out, some of which allowed testing the effects of different uptake blockers on the ${ }^{3} \mathrm{H}-\mathrm{NA}$ labeling. In 3 cases each, the following drugs were added or not to the preincubation and incubation media: (1) $10 \mu \mathrm{M}$ nonradioactive 5-HT (5-hydroxytryptamine oxalate salt, 5-HT, Sigma) to exclude the possibility of a crossspecific uptake into 5-HT axons (Descarries et al., 1975); (2) $5 \mu \mathrm{M}$ GBR12909 (GBR, Research Biochemicals), a selective inhibitor of uptake by dopamine (DA) neurons, to prevent eventual accumulation of ${ }^{3} \mathrm{H}$ NA into DA axons (Audet et al., 1988); (3) $5 \mu \mathrm{M}$ desipramine hydrochloride (DMI, Merrell) to verify the specificity of the uptake of NA into NA axons (Doucet et al., 1988).

The slices were fixed with $3.5 \%$ glutaraldehyde in $0.1 \mathrm{M}$ cacodylate buffer, postfixed with osmium tetroxide vapors, dehydrated through a graded series of ethanol, and flat-embedded in Epon. Sections, $4 \mu \mathrm{m}$ thick, of their entire surface were cut dry on a Polycut microtome (Reichert Jung). These semithin sections were mounted on gelatin-chromalum-coated slides using absolute ethanol and stored at $60^{\circ} \mathrm{C}$ for $48 \mathrm{hr}$. They were then coated by dipping in Ilford K-5 nuclear emulsion diluted $1: 1$ with water and developed in D-19 after $15 \mathrm{~d}$ of radioautographic exposure (for technical details, see Doucet et al., 1988).

Quantification of innervation density. The labcled varicosities (aggrcgates of silver grains) were counted directly from the light microscope radioautographs, using a Leitz Orthoplan microscope equipped with a $16 \times$ PlanApo lens and connected through a video camera (Hitachi 120; $244 \times 320$ pixels) to a microcomputer image-analysis system (Dapple, Imageplus + ). After digitization of the microscopic image displayed on the video screen, gray scale selection of the binary image was adjusted on each microscopic field so as to match the silver grain clusters observed in the light microscope. Correction for feature fusion was carried out as described in Doucet et al. (1988), where the average number of varicosities represented by binary image features of various sizes was determined by light microscopy.

Counts were obtained from 7 cytoarchitectonic areas at each of the 3 horizontal levels spanning the ventral two-thirds of hippocampus. The regions cxamined were the subiculum (SUB), 3 sectors of Ammon's horn (CA1, CA3-a, CA3-b) and the medial blade (DG-mb), crest (DGc), and lateral blade (DG-lb) of the DG. The exact areas (sectors) to be counted consisted of columns comprising 4-8 rectangular counting windows according to the hippocampal region examined (Fig. 1). From one section and one rat to another, the columns were localized as reproducibly as possible with the aid of low-magnification drawings of each section. The choice of wide and thin counting windows $(125 \times 330 \mu \mathrm{m})$ allowed for accurate sampling of the different laminae in every region. In Ammon's horn and DG, the second or third window always coincided with the pyramidal and the granule cell layers (see Fig. 1).

The results were first expressed as numbers of labeled sites per surface unit $\left(\mathrm{mm}^{2}\right)$ of radioautograph. In order to transform these inital values into numbers of varicosities per $\mathrm{mm}^{3}$ of tissue, 3 other parameters were determined experimentally using both CA3-b and DG-c samples. (1) To determine the percentage of labeled varicosities detected at the chosen duration of radioautographic exposure, serial $0.5-\mu \mathrm{m}$-thick sections were processed and developed after different periods of exposure ( 6 series of 6 successive $0.5-\mu \mathrm{m}$-thick sections; $3-30 \mathrm{~d}$ ) and a best-fit curve was constructed of the relationship between number of varicosities and duration of exposure. The counts at $15 \mathrm{~d}$ were then transformed using the ratio between the numbers at this time interval and the theoretical maximum to correct for incomplete detection at the chosen exposure time. (2) A second transformation was needed to compensate for the lack of transparency to tritium in $4-\mu \mathrm{m}$-thick sections. Counts were obtained from adjacent pairs of 0.5 - and $2-\mu \mathrm{m}$-thick sections to obtain a ratio for converting the values for $4-\mu \mathrm{m}$-thick sections into their equivalent for a tissue thickness of $0.5 \mu \mathrm{m}$ (fully transparent to tritium). The third parameter required for the stereological extrapolation was the diameter of the NA varicosities. For this purpose, electron microscope radioautographs were prepared from single thin sections and developed with paraphenylenediamine after 3-5 months of exposure according to standard techniques (Descarries and Beaudet, 1983). All labeled sites encountered in the sections from CA3 and the DG were then photographed at an original magnification of $14,000 \times$, until more than 130 identifiable profiles from each area were available. On photographs printed at a final magnification of $36,000 \times$, the equivalent circle diameter $(\sqrt{ }\{4 A / \pi\})$ was determined from length and breadth measurements obtained with the image-analysis system.

Extrapolation to a volumetric unit of tissue $\left(\mathrm{mm}^{3}\right)$ was then obtained from the stereological formula $N=n^{\prime \prime} \times 1000 /(t+d-2 h)$, where $n^{\prime \prime}$ is the doubly transformed value per $\mathrm{mm}^{2}$ of radioautograph; $t$, the 0.5 $\mu \mathrm{m}$ tissue thickness; $d$, the mean diameter of labeled hippocampal NA varicosities; and $h$, the height of lost caps, i.e., top portions of labeled varicosities insufficiently large to induce a detectable signal $(0.1 \mu \mathrm{m}$, according to Lapierre et al., 1973).

Statistical analyses. One- and two-factor analyses of variance (ANOVA) were applied to the regional and laminar NA quantification values using the Statview $512+$ program. Two-factor ANOVA located differences between the mean values from the various horizontal levels, regions or laminae. One-factor ANOVA was then applied for a more detailed analysis of eventual differences between individual values in each level, region or lamina. Significance was determined with the Fischer PLSD a posteriori test.

\section{Results}

\section{Radioautographic visualization}

As illustrated in Figures 1 and $2,{ }^{3} \mathrm{H}-\mathrm{NA}$ uptake labeling was prominent in all regions of the hippocampus. At the light mi-

Figure 1. Light microscope radioautograph of the whole hippocampus illustrating the anatomical sectors in which the NA innervation was quantified. Horizontal section $3.9 \mathrm{~mm}$ above the interaural line, as indicated in the inset. The rows of rectangles designate the exact areas where the labeled axonal varicosities were counted as described in Materials and Methods. Each of these counting windows measured $125 \times 330 \mu \mathrm{m}$ of section. The differcnt hippocampal scetors arc designated according to Baycr (1985): $S U B$ for subiculum; $C A 1, C A 3-a$, and $C A 3-b$, Ammon's horn; $D G-m b, D G-c$, and $D G-l b$, medial blade, crest, and lateral blade of the dentate gyrus. The various layers in each region are labeled alongside their respective counting windows and abbreviated as follows: $p y r$, stratum pyramidale; mol, stratum moleculare; or, stratum oriens; $l u c$, stratum lucidum; $\mathrm{rad}$, stratum radiatum; $1 \mathrm{~mol}$, stratum lacunosum-moleculare; $g$, granule cell layer; $p m$, polymorph cell layer. Even at this low magnification, the numerous NA-labeled varicosities (aggregates of silver grains) are individually discernible (see also Fig. 2). There is an obvious predilection of the NA innervation for the stratum moleculare of SUB and stratum lacunosum-moleculare of CA1, stratum lucidum of CA3-a and CA3-b, and polymorph layer of DG. Note the small number of labeled varicosi ies in the pyramidal cell layer of Ammon's horn and granule cell layer of DG. At this level, NA varicosities are virtually absent in the alveus and fimbria (Fi). Scale bar, $500 \mu \mathrm{m} . \times 70$. 


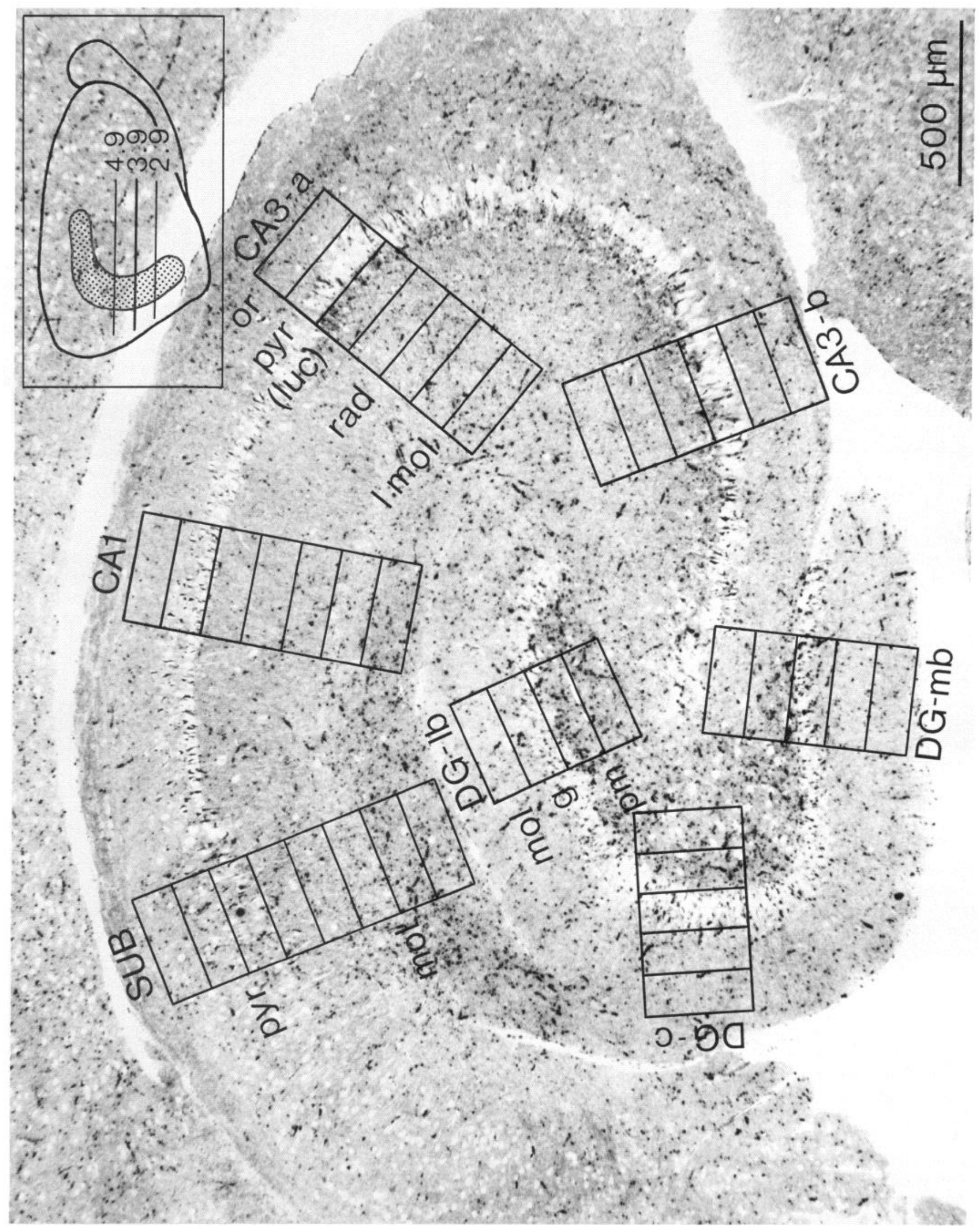


croscopic level, the labeled sites were detected in the form of small and dense aggregates of silver grains, often aligned in short beaded rows, typical of axon varicosities. In electron microscopic radioautographs from either the CA3-b or the DG-c region (Fig. 3), more than $70 \%$ of all accumulations of silver grains $(n=262)$ could indeed be readily assigned to axon varicosities $(n=187)$, i.e., axonal enlargements containing aggregated synaptic vesicles. Other clusters of silver grains $(n=32)$ overlaid transverse or longitudinal profiles of unmyelinated axon segments, while a third category was not definable in terms of underlying cellular constituents $(n=43)$. The average diameter of the sectional profiles of labeled varicosity was $0.59 \pm 0.16$ $\mu \mathrm{m}$ (SD) and $0.59 \pm 0.19 \mu \mathrm{m}$ (SD) in the CA3-b and DG-c sectors, respectively. The labeled varicosities showed no predilection for the immediate vicinity of blood vessels and were rarely apposed to nerve cell bodies. In the 7 hippocampal sectors examined, the addition of nonradioactive 5-HT, or of GBR12909 , had no apparent effect on the number of labeled sites. In contrast, varicosity labeling was virtually absent in every slice incubated in the presence of DMI.

\section{General topography}

The hippocampal NA innervation was heterogeneously distributed, as emphasized in previous descriptions (e.g., Blackstad et al., 1967; Loy et al., 1980; see also Milner and Bacon, 1989). At all 3 horizontal levels examined, 3 large crescentic zones stood out as the most densely NA innervated (Fig. 1). These corresponded, respectively, to (1) most of the molecular layer of SUB and the entire lacunosum-moleculare layer of CA1, (2) the whole polymorph layer of DG, and (3) a narrow zone in both CA3-a and CA3-b, bordering the pyramidal cell layer on its apical side (stratum lucidum). The NA innervation was less dense throughout the stratum oriens and stratum radiatum of Ammon's horn, as well as in the stratum moleculare of DG. It was even sparser in the compact cell layers, the pyramidal of Ammon's horn and granular of DG, where only occasional rows of varicosities were seen (Fig. 2, $B-H$ ). At the periphery of Ammon's horn, the alveus was almost totally devoid of labeled terminals (Fig. 2C).

\section{Quantified distribution}

The percentage of varicosities detected in light microscope radioautographs exposed for $15 \mathrm{~d}$ was $41 \%$ of the theoretical maximum determined from serial semithin sections exposed for different periods of time. A comparison of counts from adjacent 0.5 - and $2.0-\mu \mathrm{m}$-thick sections showed that $53 \%$ of the number of varicosities recorded from a tissue thickness of $2 \mu \mathrm{m}$ or more would be present in a tissue thickness of $0.5 \mu \mathrm{m}$ entirely transparent to tritium. Using these correction factors and the equivalent circle diameter measured by electron microscopic radioautography, initial counts of labeled sites could be stereologically converted into numbers of varicosities $/ \mathrm{mm}^{3}$ of tissue (innervation density) for every region and layer of the hippocampus.

Table 1 gives the mean density of NA innervation for the 3 horizontal levels in the 7 hippocampal sectors examined. In most sectors, there was a gradual increase from dorsal to ventral, resulting in a $21 \%$ difference in average density (all regions) between levels 4.9 and $2.9 \mathrm{~mm}(p<0.01)$. The mean value for each region showed a 2 -fold increase between the lowest (CA1: 1.2 million) and the highest sectors (DG-c: 2.5 million) ( $p<$ 0.001 ). Marked differences were also seen between CA1 and all other regions, as the average density abruptly dropped from 2.2 million in SUB to 1.2 million in CA1 $(p<0.001)$, returning to the 2 million range in $\mathrm{CA} 3-\mathrm{a}$ and $\mathrm{CA} 3-\mathrm{b}$, as well as throughout DG. The mean density in DG-c (2.5 million) was the highest of all sectors.

The last line of Table 1 gives the average densities for the 3 main subdivisions of the hippocampus (SUB, Ammon's horn, DG), and for this brain region as a whole (last figure on the right). These average densities decrease from SUB (2.2 million) to Ammon's horn (1.7 million) and reach their highest value in DG (2.4 million). Both SUB and DG differ significantly from Ammon's horn $(p<0.001)$. The average density for all sectors amounts to $2.1 \pm 0.1 \mathrm{million}$ varicosities $/ \mathrm{mm}^{3}$ of tissue.

Tables 2 and 3 summarize the data on laminar innervation density. In each region, the values for the different layers show a tendency to increase from level $4.9 \mathrm{~mm}$ to $2.9 \mathrm{~mm}$, but these differences are not statistically significant. In SUB, the mean density of the moleculare layer is more than twice that of the pyramidal cell layer $(p<0.001)$ (Table 2). Within Ammon's horn, every layer of CA1 has a significantly lower density than its CA3-a and CA3-b counterpart, except for the stratum lacunosum-moleculare, where the density is relatively high as in CA3-a. The density of the CA1 pyramidal cell layer is the lowest of all hippocampus. Significant variations between layers are also seen within the $2 \mathrm{CA} 3$ sectors, in which the pyramidal cell layer exhibits again a very low density, while the underlying stratum lucidum displays a 3-fold greater density $(p<0.001)$. Considerable differences are also found in the DG (Table 3), where the mean density of the polymorph layer (hilus) is almost 3 times that of the granule cell layer $(p<0.001)$. In the crest of the DG (DG-c), the polymorph layer has the highest density of all hippocampus.

\section{Discussion}

\section{Methodological considerations}

The foregoing results were obtained by radioautographic detection of NA uptake and storage sites after incubation of brain slices with micromolar concentrations of the tritiated amine in the presence of a 10 -fold higher concentration of nonradioactive 5-HT. The biological bases for such labeling have been discussed elsewhere, and earlier investigations have formally demonstrated its specificity in visualizing NA terminals (Descarries and Beaudet, 1983). In a previous study on cerebral cortex (Doucet et al., 1988), we showed total eradication of this ${ }^{3} \mathrm{H}-\mathrm{NA}$ labeling in the presence of DMI and could verify with electron microscope radioautography that axonal varicosities, as opposed to intervaricose segments, were the main $(>80 \%)$, if not exclusive, source of tracer accumulations sufficiently strong to be detectable by light microscopy.

The concurrent experiments carried out in the presence of the highly selective DA neuron uptake blocker GBR-12909 failed to demonstrate significant reductions in the hippocampal ${ }^{3} \mathrm{H}$ NA labeling, while such differences were readily appreciated in DA-innervated areas of the cerebral cortex (Audet et al., 1988). Preliminary experiments carried out with ${ }^{3} \mathrm{H}-\mathrm{DA}$ under conditions most favorable to a specific labeling of DA terminals had indeed shown only exceedingly sparse DA innervation at the 3 hippocampal levels examined here, in accordance with previously demonstrated patterns of DA fiber distribution in this part of the brain (Verney et al., 1985). In this context, it was obvious that the presence of rare DA terminals would not significantly interfere with the counts of the abundant NA varicosities, so that the use of GBR-12909 was discontinued. 
Table 1. Regional density of NA innervation in hippocampus $\left(10^{6}\right.$ varicosities $/ \mathrm{mm}^{3}$ of tissue; means $\perp$ SEM)

\begin{tabular}{|c|c|c|c|c|c|c|c|c|}
\hline Level & SUB & $\mathrm{CA} 1$ & CA3-a & CA3-b & $\mathrm{DG}-\mathrm{mb}$ & DG-c & DG-lb & Means \\
\hline $4.9 \mathrm{~mm}$ & $2.1 \pm 0.3$ & $1.0 \pm 0.04$ & $1.8 \pm 0.2$ & 0.1 & $2.0 \pm 0.2$ & $2.4 \pm 0.2$ & $2.1 \pm 0.3$ & $1.9 \pm$ \\
\hline $3.9 \mathrm{~mm}$ & $2.0 \pm 0.3$ & $1.3 \pm 0.2$ & $2.1 \pm 0.2$ & $1.7 \pm 0.2$ & $2.3 \pm 0.3$ & $2.4 \pm 0.2$ & $2.5 \pm 0.3$ & $2.1 \pm 0.1$ \\
\hline $2.9 \mathrm{~mm}$ & $2.3 \pm 0.2$ & $1.4 \pm 0.3$ & $2.2 \pm 0.4$ & $2.1 \pm 0.2$ & $2.7 \pm 0.4$ & $2.8 \pm 0.5$ & $2.4 \pm 0.4$ & $2.3 \pm 0.1$ \\
\hline Mean & $2.2 \pm 0.2$ & $1.2 \pm 0.1$ & $2.0 \pm 0.2$ & $1.7 \pm 0.1$ & $2.3 \pm 0.2$ & $2.5 \pm 0.2$ & $2.3 \pm 0.2$ & - \\
\hline & $2.2 \pm 0.2$ & \multicolumn{3}{|c|}{ Ammon's horn: $1.7 \pm 0.1$} & \multicolumn{3}{|c|}{ Dentate gyrus: $2.4 \pm 0.1$} & $2.1 \pm 0.1$ \\
\hline
\end{tabular}

Results expressed in $10^{6}$ terminals $/ \mathrm{mm}^{3}$ of tissue as explained in Materials and Methods. In this and following tables, the means \pm SEM are from 6 rats at levels $\mathrm{H} 4.9$ and $3.9 \mathrm{~mm}$, and from 5 rats at level $\mathrm{H} 2.9 \mathrm{~mm}$. The hippocampal regions are designated according to Bayer (1985) (see legend of Fig. 1 for abbreviations). On the right are the means for all regions at each horizontal level examined. The second to last line shows the means for each region. The bottom line gives the means for the 3 major anatomical subdivisions (subiculum, Ammon's horn, dentate gyrus) and for the whole of the hippocampus (last value).

$\begin{array}{lll}\begin{array}{l}\text { Statistical analysis of interregional differences: } p<0.005 \\ \text { SUB vs CA1 }\end{array} & \text { CA1 vs all } & \text { DG-mb vs CA1 } \\ \text { SUB vs CA3-b* } & \text { (CA1 vs CA3-b*) } & \text { DG-mb vs CA3-b } \\ \text { CA3-a vs CA1 } & \text { DG-c vs CA1 } \\ \text { CA3-a vs DG-c } & \text { DG-c vs CA3-a } \\ & \text { DG-c vs CA3-b } \\ \text { CA3-b vs SUB* } & \\ \text { CA3-b vs CA1 } & \text { DG-lb vs CA1 } \\ \text { CA3-b vs DG } & \text { DG-lb vs CA3-b } \dagger \\ \text { (CA3-b vs DG-lb } \dagger) & \end{array}$

In a study aimed at assessing innervation density, it was a distinct advantage to count mainly axonal varicosities as opposed to intervaricose segments. Within territories of terminal arborization, these sites of uptake and storage of the transmitter are likely to represent the major if not exclusive source of transmitter release. As thoroughly described and discussed in Doucet et al. (1988), the initial numbers of labeled sites per $\mathrm{mm}^{2}$ of semithin section radioautographs had to undergo several transformations to be expressed in number of labeled varicosities per $\mathrm{mm}^{3}$ of tissue. At the time of counting, correction for binary image fusion was performed on the basis of previous evaluations of the average number of labeled varicosities represented by features categorized according to their area. Subsequent corrections for incomplete detection at the exposure time of the counts, and for the lack of total transparency of the sections to tritium, were also based on experimental data. Last, the average diameter of the labeled varicosities could be measured in electron mi- croscope radioautographs of the same material and from 2 of the anatomical regions examined (DG-c and CA3-b). In this setting, simple stereological extrapolation was likely to provide a reasonable estimate of the true density of regional and laminar innervation (Doucet et al., 1988).

\section{Density of $N A$ innervation in adult rat hippocampus}

The average density of 2.1 million NA varicosities $/ \mathrm{mm}^{3}$ of tissue represented a total number of more than $10^{8} \mathrm{NA}$ axon terminals for this whole brain region (volume of $56 \mathrm{~mm}^{3}$, according to Coleman et al., 1987; see also West et al., 1978). This innervation density was almost twice as high as that recently reported for 7 distinct areas in the anterior half of adult rat cerebral cortex $\left(1.2 \times 10^{6} / \mathrm{mm}^{3}\right.$ according to Audet et al., 1988). Interestingly, there is a difference of the same order in the endogenous amine content of these 2 brain regions [ $2.6 \mathrm{ng} / \mathrm{mg}$ protein (Reader and Grondin, 1987) versus $6.2 \mathrm{ng} / \mathrm{mg}$ of protein (average of mea-

Figure 2. $A-H$, Light microscope radioautographs at higher magnification exemplifying the patterns of NA innervation in each of the 7 hippocampal sectors examined. Same horizontal level as in Figure 1. The different layers are labeled in each sector. See Figure 1 legend for list of abbreviations. Scale bar for all radioautographs, $100 \mu \mathrm{m} . \times 160 . A$, The subiculum $(S U B)$ is relatively densely NA innervated. The number of labeled varicosities is relatively even throughout the stratum pyramidale $(p y r)$ and increases gradually within the stratum moleculare (mol) (see also Fig. 1). $B$, The average NA innervation of CAl is the lowest of all the hippocampus. Note the virtual absence of labeled varicosities in the compact pyramidal cell layer (pyr) except for an occasional traversing fiber. The stratum oriens (or) is only sparsely innervated and there is a sharp increase in innervation density from the stratum radiatum $(\mathrm{rad})$ to the stratum lacunosum-moleculare $(\mathrm{lmol})$. An area of lighter-colored tissue at the rad-lmol border shows fewer NA terminals than the adjacent tissue. $C$ and $D$, In $C A 3-a(C)$ and $C A 3-b(D)$, the overall density of NA innervation is again relatively high. In both these sectors, the strong innervation in the stratum lucidum [ (luc)] portion of stratum radiatum (rad) contrasts strongly with the low number of labeled varicosities in the overlying pyramidal cell layer (pyr). Below the stratum lucidum [(luc)], there is a progressive increase in density from $\mathrm{rad}$ to $1 \mathrm{~mol}$ as shown in Figure 1. In CA3-a, the NA varicosities of the stratum oriens (or) appear concentrated in the outer portion of this layer, next to the non NA-innervated alveus (alv) (see also Fig. 1). $E-H$, Overall, the dentate gyrus $(D G)$ has the densest NA innervation in the hippocampus. This innervation is similarly distributed among its 3 sectors: medial blade $(D G-m b, E)$, crest $(D G-c, G)$ and lateral blade $(D G-l b, H)$. The molecular layer $(\mathrm{mol})$ is evenly NA innervated, the granule cell layer $(\mathrm{g})$ only sparsely, and the polymorph cell layer $(\mathrm{pm})$, particularly in the crest, has the highest laminar density of NA innervation in all the hippocampus. $F$ is an unretouched reproduction of the area framed in $E$, as edited and printed by the image analysis system. Note the good match between the real and binary images of the labeled varicosities. 


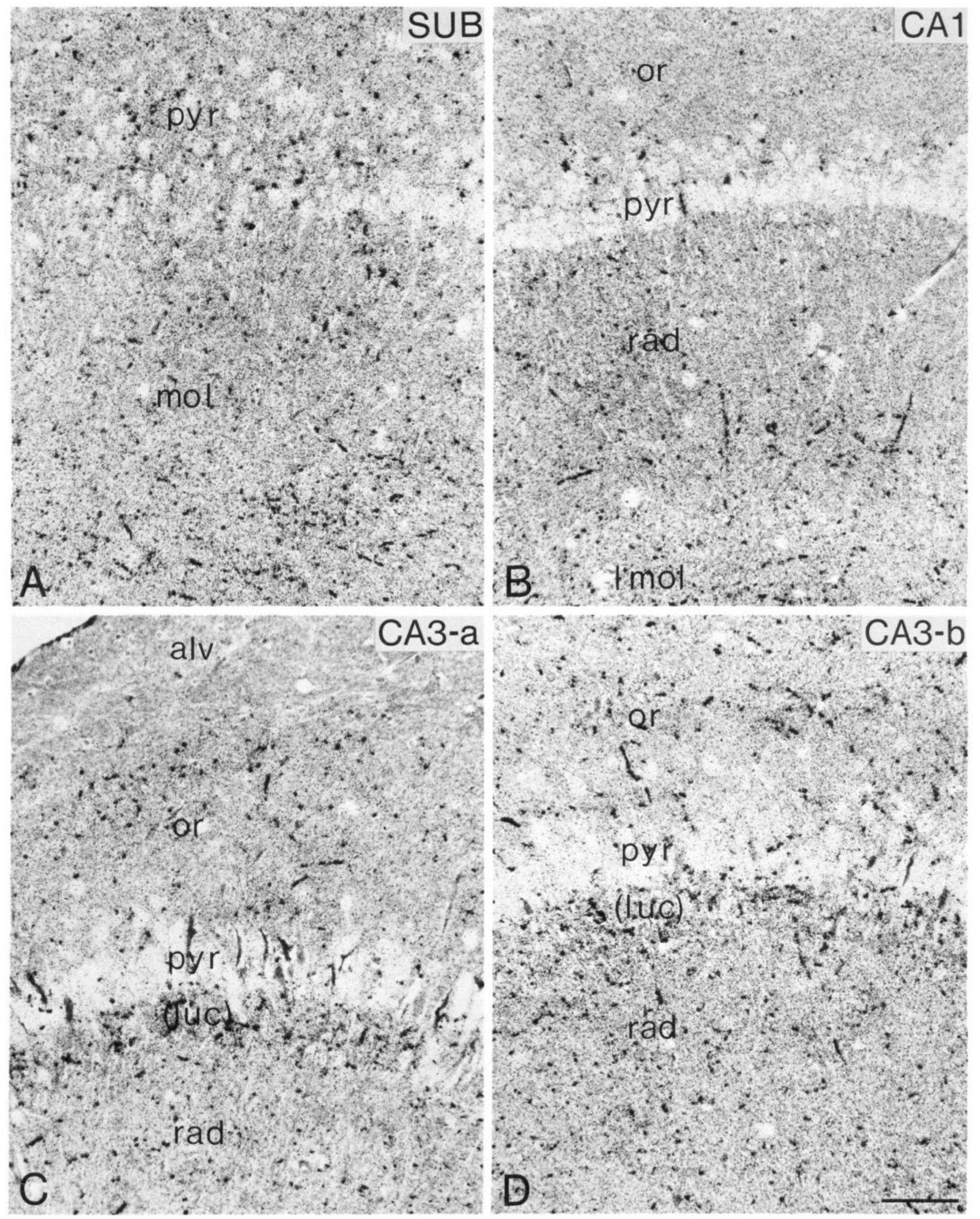



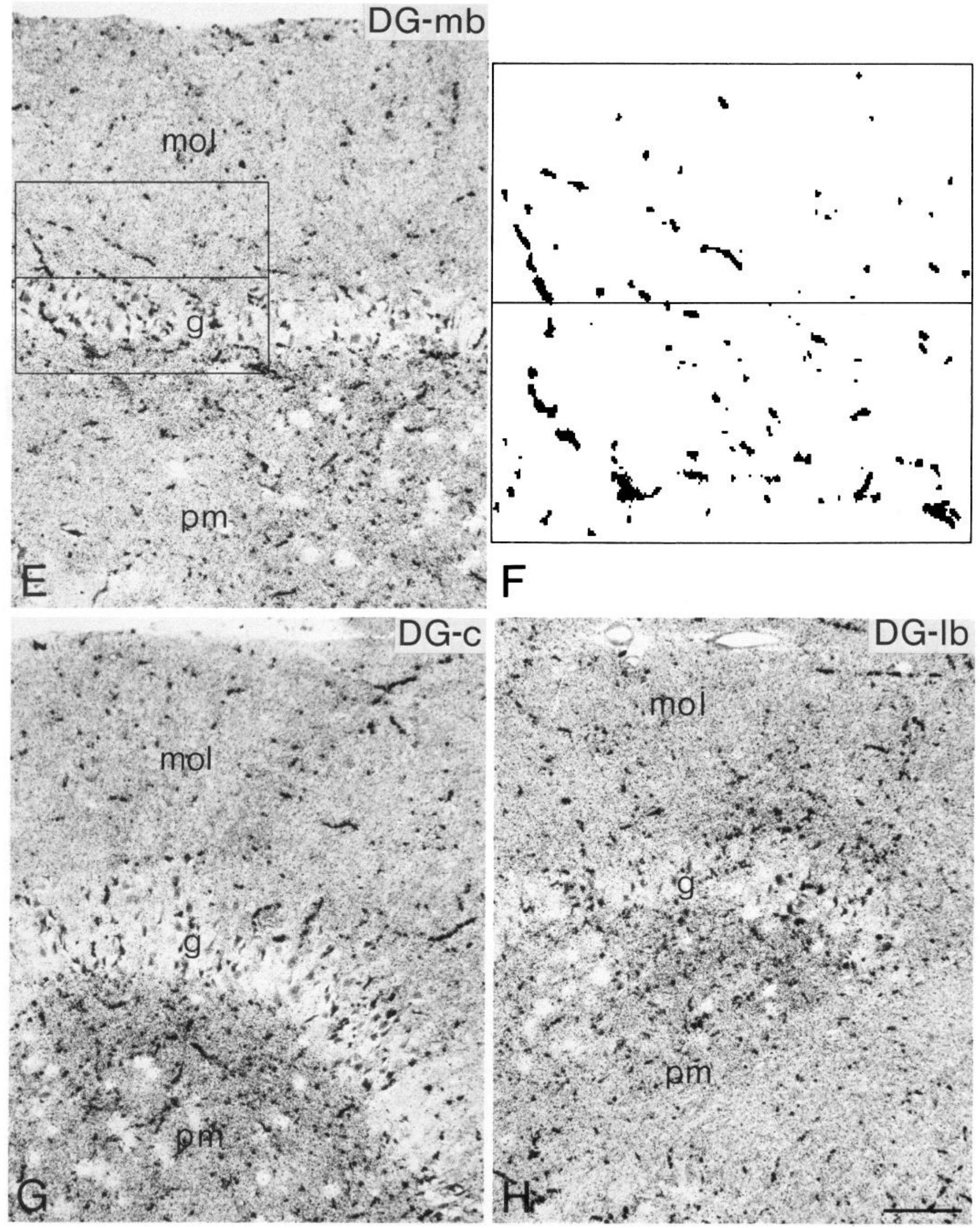

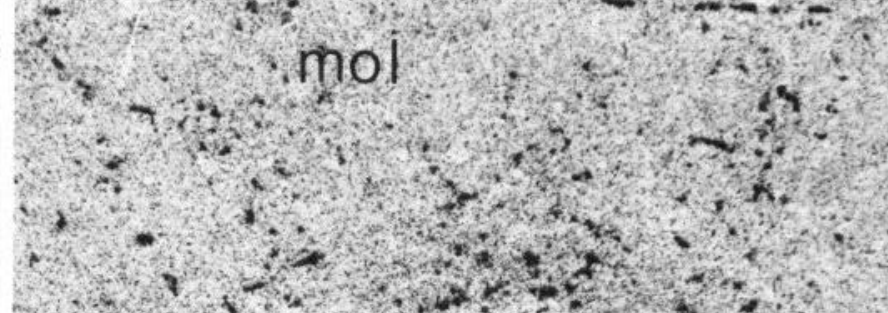

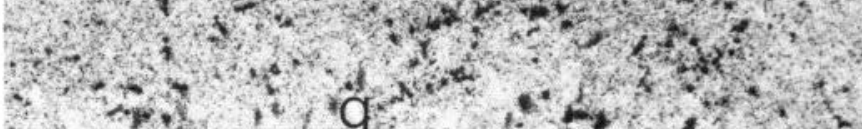
W

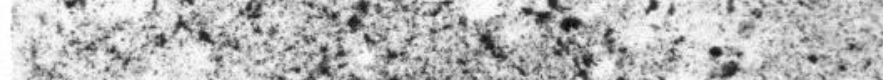

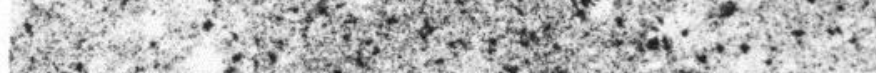

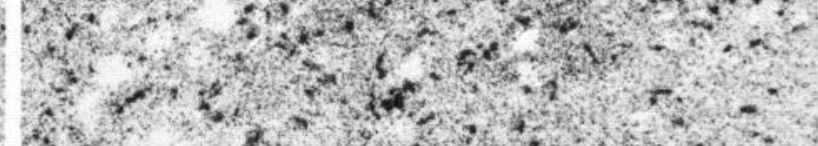

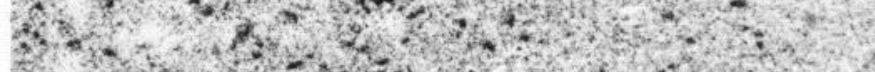

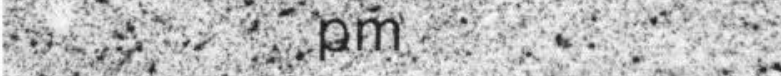

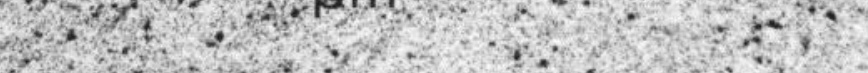

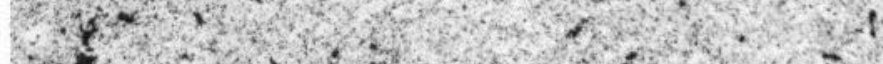

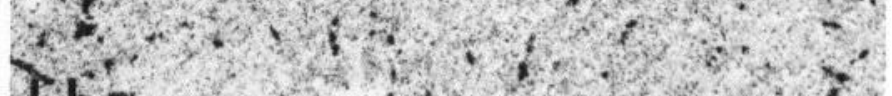

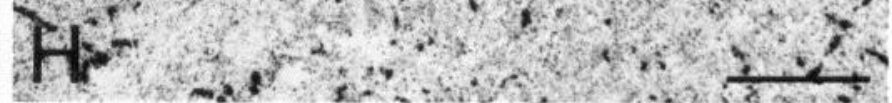



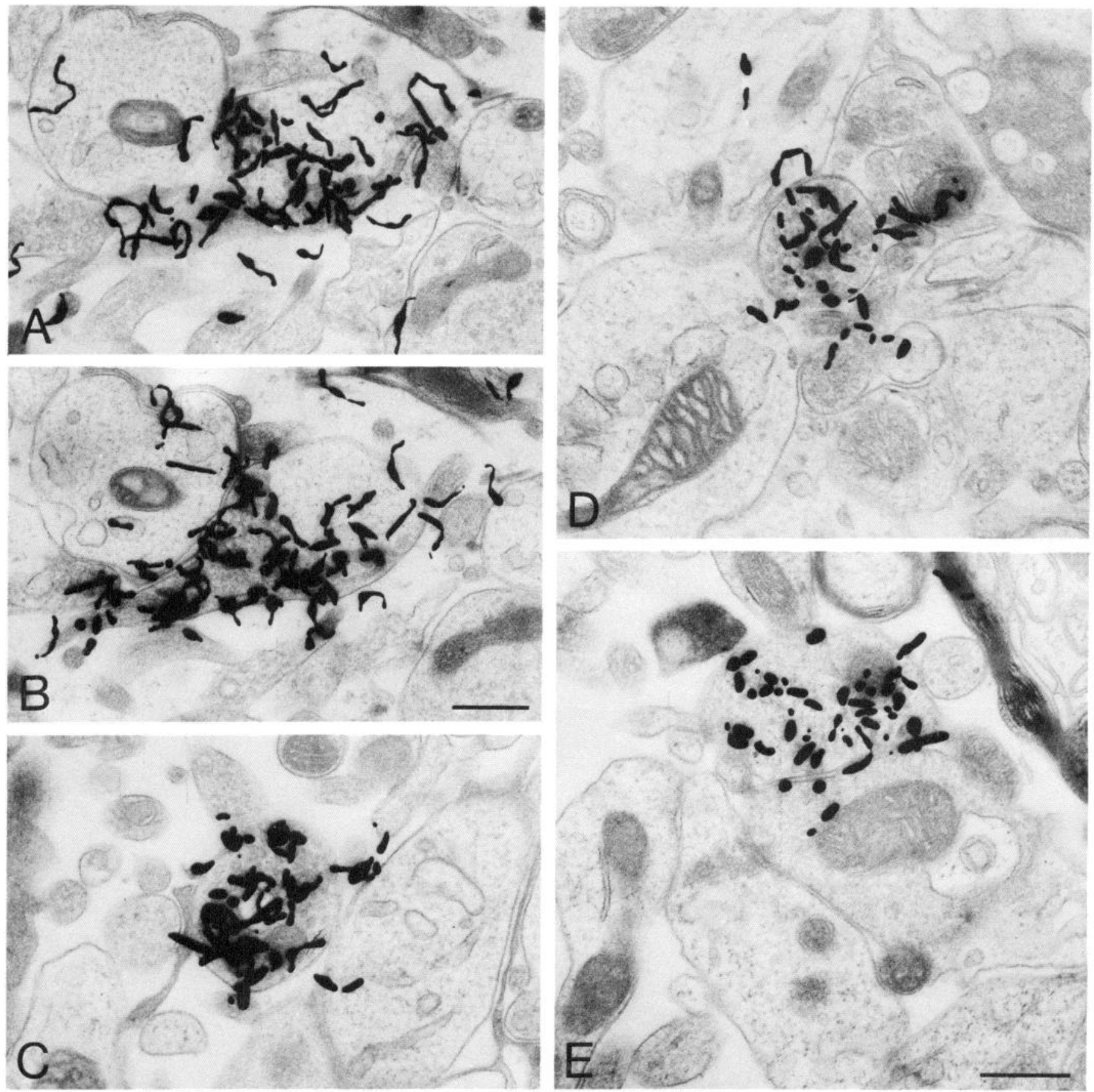

Figure 3. $A-E$, Electron microscope radioautographs of ${ }^{3} \mathrm{H}-\mathrm{NA}$-labeled axon varicosities from the dentate gyrus $(D G-c, A-C)$ and from Ammon's horn $(C A 3-b, D$ and $E)$. As typically found with monoamine-labeled varicosities, the silver grains are mostly accumulated over unmyelinated axon dilations filled with small, clear synaptic vesicles, accompanied by occasional larger vesicles and mitochondria. Scale bars, $0.5 \mu \mathrm{m}$. $A$ and $B$, $\times 28,000 ; C-E, \times 34,000$. $A$ and $B$, This densely labeled NA varicosity from the polymorph layer of $D G-c$ is shown in 2 adjacent thin sections. It partially engulfs an adjacent process, probably dendritic in nature, but the area of membrane interface is obscured by the tightly packed overlying grains. $C$, This circular profile of labeled varicosity is from the molecular layer of $D G-c$. It illustrates the most common appearance of labeled NA terminals. The poor morphological preservation of incubated tissue presumably accounts for the widening of the extracellular space. $D$, This NA axonal varicosity from the stratum lucidum of $C A 3-b$ is nested between several other axonal processes and 2 dendrites; it fails to show any evidence of a synaptic junction. $E$, This large NA axonal varicosity from the stratum oriens of $C A 3-b$ appears to be in symmetrical synaptic contact with an adjacent dendrite, which also receives a second synapse from another large adjacent process.

surements by Brownstein et al., 1974; St. Laurent et al., 1975; and Versteeg et al., 1976)], suggesting a similar amine content per varicosity (see also below).

The overall density of hippocampal NA innervation was found to be $20 \%$ higher ventrally than dorsally, substantiating previous claims of a heterogeneous distribution along the septotemporal axis (Gage et al., 1978; Loy et al., 1980). In addition to endogenous NA levels, the high-affinity uptake of ${ }^{3} \mathrm{H}-\mathrm{NA}$ (StormMathisen and Guldberg, 1974) and the density of alpha ${ }_{1}$-adrenoceptors (Young and Kuhar, 1980; Jones et al., 1985) have 


\begin{tabular}{|c|c|c|c|c|c|c|}
\hline Layer & Level & SUB & CAl & CA3-a & CA3-b & Mean \\
\hline \multirow[t]{4}{*}{ Oriens } & 4.9 & - & $0.4 \pm 0.1$ & $0.9 \pm 0.2$ & $1.1 \pm 0.1$ & \\
\hline & 3.9 & - & $0.7 \pm 0.2$ & $1.1 \pm 0.2$ & $1.3 \pm 0.1$ & \\
\hline & 2.9 & - & $0.7 \pm 0.2$ & $1.7 \pm 0.3$ & $1.7 \pm 0.3$ & \\
\hline & Mean & & $0.6 \pm 0.1$ & $1.2 \pm 0.2$ & $1.4 \pm 0.1$ & $1.1 \pm 0.1$ \\
\hline \multirow{4}{*}{ Pyramidal } & 4.9 & $1.1 \pm 0.2$ & $0.3 \pm 0.3$ & $0.9 \pm 0.1$ & $0.8 \pm 0.1$ & \\
\hline & 3.9 & $1.1 \pm 0.2$ & $0.5 \pm 0.1$ & $1.3 \pm 0.3$ & $0.9 \pm 0.2$ & \\
\hline & 2.9 & $1.7 \pm 0.3$ & $0.5 \pm 0.2$ & $1.6 \pm 0.3$ & $1.3 \pm 0.2$ & \\
\hline & Mean & $1.3 \pm 0.1$ & $0.4 \pm 0.1$ & $1.2 \pm 0.2$ & $1.0 \pm 0.1$ & $1.0 \pm 0.1$ \\
\hline \multirow[t]{4}{*}{$\begin{array}{l}\text { Radiatum } \\
\text { (lucidum) }\end{array}$} & 4.9 & & $0.9 \pm 0.1$ & $\begin{array}{c}2.0 \pm 0.2 \\
(3.2 \pm 0.3)\end{array}$ & $\begin{array}{c}1.8 \pm 0.2 \\
(2.1 \pm 0.2)\end{array}$ & \\
\hline & 3.9 & & $1.3 \pm 0.2$ & $\begin{array}{c}2.5 \pm 0.2 \\
(3.7 \pm 0.4)\end{array}$ & $\begin{array}{c}2.3 \pm 0.2 \\
(3.1 \pm 0.5)\end{array}$ & \\
\hline & 2.9 & & $1.2 \pm 0.4$ & $\begin{array}{c}2.4 \pm 0.5 \\
(3.4 \pm 0.7)\end{array}$ & $\begin{array}{c}2.5 \pm 0.3 \\
(3.8 \pm 0.3)\end{array}$ & \\
\hline & Mean & & $1.1 \pm 0.1$ & $\begin{array}{c}2.3 \pm 0.2 \\
(3.4 \pm 0.3)\end{array}$ & $\begin{array}{c}2.2 \pm 0.2 \\
(3.0 \pm 0.3)\end{array}$ & $\begin{array}{c}1.9 \pm 0.1 \\
(3.2 \pm 0.2)\end{array}$ \\
\hline \multirow[t]{4}{*}{ Moleculare } & 4.9 & $2.7 \pm 0.4$ & $1.6 \pm 0.2$ & $2.3 \pm 0.4$ & - & \\
\hline & 3.9 & $3.0 \pm 0.4$ & $2.2 \pm 0.2$ & $2.5 \pm 0.3$ & - & \\
\hline & 2.9 & $2.6 \pm 0.2$ & $2.5 \pm 0.4$ & $2.3 \pm 0.4$ & - & \\
\hline & Mean & $2.8 \pm 0.2$ & $2.1 \pm 0.2$ & $2.4 \pm 0.2$ & & $2.4 \pm 0.1$ \\
\hline
\end{tabular}

Results expressed in $10^{6}$ terminals $/ \mathrm{mm}^{3}$ of tissue as explained in Materials and Methods. The values in parentheses refer to the stratum lucidum component of the stratum radiatum.

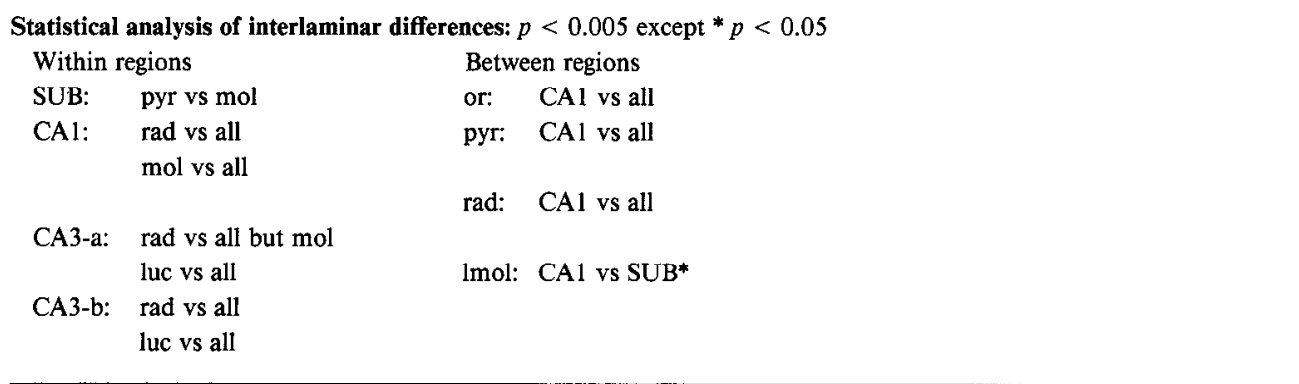

also been reported to be higher in the ventral than dorsal hippocampus. Given that the hippocampus is functionally organized in lamellae transverse to the septotemporal axis (Andersen et al., 1971, 1973), this might imply that the locus coeruleus projections modulating impulse flow through these lamellar circuits (Winson and Dahl, 1985) exert stronger effects in the ventral than the dorsal hippocampus.

Current knowledge of the 3 pathways of projection from the locus coeruleus to the hippocampus (Moore, 1975; Loy et al., 1980; Gage et al., 1983; Haring and Davis, 1985) indicates that the fasciculus cinguli reaching the hippocampus dorsally distributes its NA fibers mostly ventrally, in particular to SUB, lacunosum-moleculare layer of Ammon's horn, and ventral DG. The fimbria-fornix entering dorsally carries NA fibers that arborize mainly to CA3 and the polymorph layer (hilus) of the DG (mostly dorsally according to Haring and Davis, 1985). The ventral amygdaloid bundle entering the hippocampus ventrally would provide a significant fraction of the NA innervation in the whole hippocampal formation (40\% according to Gage et al., 1983). In our material from the ventral two-thirds of the hippocampus, the cingulate bundle could therefore be largely responsible for the large crescentic zone of dense NA innervation in the molecular layer of SUB and lacunosum-moleculare of $\mathrm{CA} 1$; the fimbria-fornix would predominantly contribute to the dense NA innervation in the stratum lucidum of CA3. Both the cingulum and ventral amygdaloid bundle might participate in the dense NA innervation of the DG hilus. Some of these regional and laminar differences in NA innervation density could thus reflect a distinct cellular origin of the parent fibers (Haring and Davis, 1983). Besides, it is well established that following denervating lesions of the hippocampus, residual NA fibers may undergo considerable sprouting and hence increase both in extent and richness of arborization (Gage et al., 1983; Peterson, 1988). Therefore, local, epigenetic, as well as genetic, factors should be playing a role in determining the distribution of these nerve terminals.

The exact number of NA neurons in rat locus coeruleus that project to the hippocampus is not yet known. However, assuming that half of them do (i.e., some 700 neurons on each side according to counts by Descarries and Saucier, 1972), it may be inferred that each locus coeruleus nerve cell body would then be issuing an average of 170,000 terminals destined to the hippocampus. This figure is all the more striking since at least some of these nerve cell bodies concomitantly project also to the 


\begin{tabular}{llllll}
\hline \multicolumn{6}{l}{ Table 3. } \\
varicosities/mmar of $^{3}$ of tissue; means \pm SEM) \\
Layer & Level & DG-mb & DG-c & DG-lb & Mean \\
\hline Molecular & 4.9 & $1.2 \pm 0.2$ & $1.3 \pm 0.1$ & $1.3 \pm 0.1$ & \\
& 3.9 & $1.8 \pm 0.2$ & $1.7 \pm 0.1$ & $1.8 \pm 0.4$ & \\
& 2.9 & $2.4 \pm 0.3$ & $2.0 \pm 0.2$ & $1.9 \pm 0.2$ & \\
& Mean & $1.7 \pm 0.2$ & $1.6 \pm 0.1$ & $1.7 \pm 0.2$ & $1.7 \pm 0.1$ \\
Granular & 4.9 & $0.8 \pm 0.2$ & $0.7 \pm 0.1$ & $1.2 \pm 0.3$ & \\
& 3.9 & $1.6 \pm 0.4$ & $1.1 \pm 0.2$ & $1.9 \pm 0.3$ & \\
& 2.9 & $1.0 \pm 0.3$ & $1.2 \pm 0.5$ & $2.0 \pm 0.2$ & \\
& Mean & $1.1 \pm 0.2$ & $1.0 \pm 0.2$ & $1.7 \pm 0.2$ & $1.3 \pm 0.1$ \\
Polymorph & 4.9 & $3.4 \pm 0.3$ & $4.2 \pm 0.3$ & $3.1 \pm 0.3$ & \\
& 3.9 & $2.9 \pm 0.4$ & $3.8 \pm 0.3$ & $3.1 \pm 0.3$ & \\
& 2.9 & $3.9 \pm 0.5$ & $4.5 \pm 0.6$ & $3.0 \pm 0.4$ & \\
& Mean & $3.4 \pm 0.2$ & $4.2 \pm 0.3$ & $3.1 \pm 0.2$ & $3.5 \pm 0.2$ \\
\hline
\end{tabular}

See footnote to Table 2 .

Statistical analysis of interlaminar differences: $p<0.005$ except $\dagger p<0.01$ and $* p<0.05$

\begin{tabular}{|c|c|c|c|}
\hline \multicolumn{2}{|c|}{ Within regions } & \multicolumn{2}{|r|}{ Between regions } \\
\hline $\mathrm{Dg}-\mathrm{mb}:$ & $\begin{array}{l}\text { all layers } \\
\text { (mol vs gr*) }\end{array}$ & gr: & DG-lb vs DG-mb $\dagger$ \\
\hline & & pm: & DG-c vs DG-mb \\
\hline DG-c: & $\begin{array}{l}\text { all layers } \\
\left.\text { (mol vs } \mathrm{gr}^{*}\right)\end{array}$ & & DG-c vs DG-lb \\
\hline DG-lb: & $\begin{array}{l}\text { pm vs mol } \\
\text { pm vs gr }\end{array}$ & & \\
\hline
\end{tabular}

cerebral cortex and/or other brain regions (Nagai et al., 1981; Room et al., 1981).

\section{Morphological correlates of regional and laminar $N A$ innervation density}

The regional density of NA innervation expressed as number of varicosities per $\mathrm{mm}^{3}$ of tissue differed significantly across the 7 hippocampal sectors examined, with averages of 2.2 million for SUB, 1.7 million for Ammon's horn, and 2.4 million for DG. Since neuronal monoamines are mostly concentrated within axonal varicosities as opposed to intervaricose segments, these values allow us to calculate a mean endogenous NA content per varicosity. Based on figures of 274 and $503 \mathrm{ng} \mathrm{NA} / \mathrm{gm}$ of tissue for Ammon's horn and DG, respectively (Loy et al., 1980), the corresponding NA contents per varicosity may be estimated at 0.16 and $0.21 \mathrm{fg}$, indicating concentrations in the order of 1450 and $1900 \mu \mathrm{g} / \mathrm{gm}$ of varicosity (in the $10^{-2} \mathrm{M}$ range). Similar values have been reported for the rat neocortex $(0.22 \mathrm{fg} /$ varicosity, $1600 \mu \mathrm{g} / \mathrm{gm}, 10^{-2} \mathrm{M}$; Audet et al., 1988), demonstrating consistency in the different territories of projection of the same neurons.

The regional density of NA innervation may also be envisaged relative to current estimates of the total number of cell bodies or axon terminals in rat hippocampus. Since the total volume of the DG is $16 \mathrm{~mm}^{3}$ (Colcman ct al., 1987), the total number of NA terminals in the DG may be estimated to be $3.8 \times 10^{7}$. The total number of cells in Sprague-Dawley rat DG is on the order of 1-2 × $10^{6}$ for the granule cell layer (Gaarskjaer, 1978; Bayer, 1982; Boss et al., 1985; West et al., 1988) and $3 \times 10^{4}$ for the hilus (Gaarskjaer, 1978). Assuming an equal number of terminals on granule and hilus cells, the average number of NA terminals per cell of the DG would be on the order of $20-40$. Within the granule cell layer itself [ $3 \mathrm{~mm}^{3}$ (Coleman et al., 1987;
West et al., 1988)], this number falls to $2-4$ per nerve cell body, emphasizing the particularly low NA innervation in this layer (Loy et al., 1980). Similar calculations may be performed for $\mathrm{CA} 3$, based on an estimated total volume of $13.3 \mathrm{~mm}^{3}$ for this hippocampal region (West et al., 1978). The average number of NA terminals per pyramidal cell of CA3 $\left(1.4 \times 10^{5}\right.$ according to Gaarskjaer, 1978) would then be on the order of 180 , a ratio significantly higher than for the dentate granule cells. Within the pyramidal cell layer itself $\left[1.5 \mathrm{~mm}^{3}\right.$ (West et al., 1978)], the number falls to $11 \mathrm{NA}$ terminals per cell body.

Without prejudging whether synaptic membrane specializations exist on all hippocampal NA varicosities, it is of interest to consider the incidence of these varicosities in relation to the total number of axon terminals in the different regions of the hippocampus. Available data on the number of synaptic junctions per surface unit of tissue (synaptic density) may be converted to a volumetric unit using the stereological formula $N_{v}=$ $N_{A} / d$ validated by Colonnier and Beaulieu (1985), where $N_{A}$ is the number of synaptic contacts per unit area and $d$ is the mean trace length of the synaptic membrane. According to values provided by Hoff et al. (1982) and Curcio and Hinds (1983) for the molecular layer of the DG, the total number of $1.5 \times 10^{9}$ synaptic terminals $/ \mathrm{mm}^{3}$ may thus be calculated, yielding a relative incidence of $1 \mathrm{NA}$ varicosity/880 synapses. This ratio could be significantly lower, however, if a considerable proportion of all axon terminals actually lack synaptic junctions. A similar calculation is possible for the stratum radiatum of CAl (based on data from Scheff et al., 1985) and gives a significantly lower number of 1 NA varicosity/1500 synapses, in keeping with the relatively low NA innervation density of this hippocampal region.

\section{Physiological correlates of regional and laminar $N A$ innervation density}

In contrast to the current understanding of the coding of information in hippocampus (Eichenbaum and Cohen, 1988), knowledge allowing us to relate hippocampal function to the different anatomical subdivisions of this brain region is limited (but see Grant and Jarrard, 1968, and Flicker and Geyer, 1982a, b). In general terms, however, it is noteworthy that the densest regional NA innervations in the hippocampus are those of the DG and SUB, which respectively correspond to its main cortical input and output stations (Hjorth-Simonsen and Jeune, 1972; Swanson and Cowan, 1977; Sorensen and Shipley, 1979).

The present data on regional and laminar innervation density can be interestingly confronted with a considerable amount of data on the distribution of the various types of adrenoceptors characterized by radioligand binding in adult rat hippocampus. The distribution of alpha, receptors corresponds closely to that of NA varicosities: high densities in CA1 stratum lacunosummoleculare (Jones et al., 1985; Goffinet and Caviness, 1986), stratum lucidum of CA3 (Jones et al., 1985), and polymorph layer and stratum moleculare of DG (Young and Kuhar, 1980; Tayrien and Loy, 1984; Jones et al., 1985); moderate to low densities in the other sectors (Young and Kuhar, 1980; Tayrien and Loy, 1984; Goffinet and Caviness, 1986). The distribution of alpha $a_{2}$ and beta receptors does not fit so well with the NA innervation: alpha $\mathrm{a}_{2}$ receptors are present in high numbers in the stratum lacunosum-moleculare of CAl but in only moderate numbers throughout $\mathrm{CA} 2$ and $\mathrm{DG}$ and low numbers in CA3 (Unnerstall et al., 1984; Bruning et al., 1987). Beta receptors do not match. The majority are of the beta ${ }_{1}$ type $\left[\right.$ beta $_{1}$ vs beta: 
85 vs $15 \%$ in CA $1 ; 65$ vs $35 \%$ in CA3; 80 vs $20 \%$ in DG (Rainbow et al., 1984)]. These are distributed in uniformly high density in CA1, low density in CA3, and moderate and high densities, respectively, in the polymorph and molecular layers of DG (Rainbow et al., 1984; Goffinet and Caviness, 1986; Lorton and Davis, 1987). Beta 2 receptors have a uniformly low distribution in CA1, CA3, and DG (Rainbow et al., 1984; Lorton and Davis, 1987). Electrophysiological characterization of hippocampal adrenoceptors in Ammon's horn has suggested that the receptors responsible for the effects of synaptically released NA in CA3 are of the alpha ${ }_{1}$ type, whereas those involved in effects produced by microiontophoretic application of NA pyramidal neurons are of the alpha ${ }_{2}$ type (Curet and de Montigny, $1988 \mathrm{a}, \mathrm{b})$. The presence of a particularly high density of NA innervation in the stratum lucidum of CA3 and the low density in the pyramidal cell layer support this conclusion.

The laminar distribution of NA varicosities within each region further suggests that the cellular targets of the action(s) of NA might differ between regions. In CA1, for example, the highest density of NA terminals is in the stratum lacunosummoleculare. These terminals are strategically located to act upon a distinct type of inhibitory interneuron physiologically characterized in this area (Lacaille and Schwartzkroin, 1988a, b). Since in CA1, tyrosine hydroxylase-immunoreactive terminals have been shown to make synaptic contact with glutamate decarboxylase-immunoreactive interneuron dendrites (Frotscher and Leranth, 1988), and since excitatory actions of NA on interneurons have been reported (Pang and Rose, 1987; Madison and Nicoll, 1988), the morphological substrate of these actions may be found in the stratum lacunosum-moleculare. Some postsynaptic effects of NA on CA1 pyramidal cell membranes (Langmoen et al., 1981; Sah et al., 1985; Lancaster and Adams, 1986; Madison and Nicoll, 1986a, b) might arise from the weak NA innervation in stratum oriens and radiatum.

In CA3, the highest density of NA terminals is found in stratum lucidum, which corresponds to the zone where mossy fibers of granule cells make excitatory synapses on CA3 pyramidal cells. The reported frequency-dependent modulation of these synapses by NA (Hopkins and Johnston, 1988) may represent the functional consequence of this innervation. However, recent studies by Milner and Bacon (1989) indicate the existence of frequent synaptic junctions between tyrosine hydroxylase-immunostained terminals and presumed pyramidal cell dendrites in the stratum lucidum of CA3. These could account for some direct effects of NA on the pyramidal cells, such as a modulation of $\mathrm{Ca}^{2+}$ currents (Gray and Johnston, 1987; Fisher et al., 1988).

In DG, the highest density of NA innervation was that of the polymorph layer. Therefore, the prime target of this NA innervation might be hilar interneurons, upon which excitatory actions of NA have indeed been reported (Pang and Rose, 1987). However, granule cells also might be directly influenced by NA, since there is a moderate NA innervation in the stratum moleculare and evidence for the presence of tyrosine hydroxylaseimmunostained synaptic terminals on dendrites in this layer (Milner and Bacon, 1989). This interrelationship might underlie the short- (Gray and Johnston, 1987; Haas and Rose, 1987; Lacaille and Schwartzkroin, 1988c) and long-lasting effects of NA on granule cell excitability (Neuman and Harley, 1983), the latter reportedly unique to the DG (Stanton and Sarvey, 1985; Hopkins and Johnston, 1988; Madison and Nicoll, 1988). As there seem to be structural differences between presumed NA terminals on hippocampal pyramidal cells versus interneurons
(Frotscher and Leranth, 1988), it will be interesting to examine further the fine structure of this innervation in relation to the various actions of NA in the different hippocampal regions. Differences in terms of both nonjunctional and junctional relationships with cellular targets might then be detected, and these could also contribute to the diversity of physiological actions of NA in the hippocampus.

\section{References}

Andersen, P., T. V. P. Bliss, and K. K. Skrede (1971) Lamellar organization of hippocampal excitatory pathways. Exp. Brain Res. 13: 222-238.

Andersen, P., B. H. Bland, and J. D. Dudar (1973) Organization of the hippocampal output. Exp. Brain Res. 17: 152-168.

Audet, M. A., G. Doucet, S. Oleskevich, and L. Descarries (1988) Quantified regional and laminar distribution of the noradrenaline innervation in the anterior half of the adult rat cerebral cortex. J. Comp. Neurol. 274: 307-318.

Bayer, S. A. (1982) Changes in the total number of dentate granule cells in juvenile and adult rats: A correlated volumetric and ${ }^{3} \mathrm{H}$-thymidine autoradiographic study. Exp. Brain Res. 46: 315-323.

Bayer, S. A. (1985) Hippocampal region. In The Rat Nervous System, Vol. 1: Forebrain and Hindbrain, G. Paxinos, ed., pp. 335-328, Academic, Australia.

Blackstad, T. W., K. Fuxe, and T. Hökfelt (1967) Noradrenaline nerve terminals in the hippocampal region of the rat and guinea pig. $Z$. Zellforsh. Mikrosk. Anat. 78: 463-473.

Boss, B. B., G. M. Peterson, and W. M. Cowan (1985) On the number of neurons in the dentate gyrus of the rat. Brain Res. 338: 144-150.

Brownstein, M., J. M. Saavedra, and M. Palkovits (1974) Norepinephrine and dopamine in the limbic system of the rat. Brain Res. 79: $431-436$.

Bruning, G., P. Kaulen, and H. G. Baumgarten (1987) Quantitative autoradiographic localization of $\alpha_{2}$-antagonist binding sites in rat brain using [ $\left.{ }^{3} \mathrm{H}\right]$ idazoxan. Neurosci. Lett. 83: 333-337.

Coleman, P. D., D. G. Flood, and M. J. West (1987) Volumes of the components of the hippocampus in the aging F344 rat. J. Comp. Neurol. 266: 300-306.

Colonnier, M., and C. Beaulieu (1985) An empirical assessment of stereological formulae applied to the counting of synaptic disks in the cerebral cortex. J. Comp. Neurol. 231: 175-179.

Curcio, C. A., and J. W. Hinds (1983) Stability of synaptic density and spine volume in dentate gyrus of aged rats. Neurobiol. Aging 4: 77-87.

Curet, O., and C. de Montigny (1988a) Electrophysiological characterization of adrenoceptors in the rat dorsal hippocampus. I. Receptors mediating the effect of microiontophoretically-applied norepinephrine. Brain Res. 475: 35-46.

Curet, O., and C. de Montigny (1988b) Electrophysiological characterization of adrenoceptors in the rat dorsal hippocampus. II. Receptors mediating the effect of synaptically-released norepinephrine. Brain Res. 475: 47-57.

Descarries, L., and A. Beaudet (1983) The use of radioautography for investigating transmitter-specific neurons. In Handbook of Chemical Neuroanatomy, Vol. 1: Methods in Chemical Neuroanatomy, A. Björklund and T. Hökfelt, eds., pp. 286-364, Elsevier, Amsterdam.

Descarries, L., and G. Saucier (1972) Disappearance of the locus coeruleus in the rat after intraventricular 6-hydroxydopamine. Brain Res. 37: $310-316$.

Descarries, L., A. Beaudet, and K. C. Watkins (1975) Serotonin nerve terminals in adult rat neocortex. Brain Res. 100: 563-588.

Doucet, G., L. Descarries, M. A. Audet, S. Garcia, and B. Berger (1988) Radioautographic method for quantifying regional monoamine innervations in the rat brain. Application to the cerebral cortex. Brain Res. 441: 233-259.

Eichenbaum, H., and N. J. Cohen (1988) Representation in the hippocampus: What do hippocampal neurons code? Trends Neurosci. 11: 244-248.

Fisher, R. E., R. Gray, and D. Johnston (1988) $\beta$-adrenoceptor modulation of calcium channels in acutely exposed CA3 pyramidal neurons of adult guinea pig hippocampus. Soc. Neurosci. Abstr. 14: 645.

Flicker, C., and M. A. Geyer (1982a) Behavior during hippocampal 
microinfusions. I. Norepinephrine and diversive exploration. Brain Res. Rev. 4: 79-103.

Flicker, C., and M. A. Geyer (1982b) Behavior during hippocampal microinfusions. IV. Transmitter interactions. Brain Res. Rev. 4: 137147.

Foote, S. L., F. E. Bloom, and G. Aston-Jones (1983) Nucleus locus coeruleus: New evidence of anatomical and physiological specificity. Physiol. Rev. 63: 844-914.

Frotscher, M., and C. Leranth (1988) Catecholaminergic innervation of pyramidal and GABAergic non pyramidal neurons in the rat hippocampus. Double label immunostaining with antibodies against tyrosine hydroxylase and glutamate decarboxylase. Histochemistry 88 : 313-319.

Fuxe, K. (1965) Evidence for the existence of monoamine neurons in the central nervous system. IV. The distribution of monoamine nerve terminals in the central nervous system. Acta Physiol. Scand. 64: $37-$ 85.

Gaarskjaer, F. B. (1978) Organization of the mossy fiber system of the rat studied in extended hippocampi. I. Terminal area related to number of granule and pyramidal cells. J. Comp. Neurol. 178: 4972.

Gage, F. H., R. G. Thompson, and J. J. Valdes (1978) Endogenous norepinephrine and serotonin within the hippocampal formation during the development and recovery from septal hyperactivity. Pharmacol. Biochem. Behav. 9: 359-367.

Gage, F. H., A. Björklund, and U. Stenevi (1983) Reinnervation of the partially deafferented hippocampus by compensatory collateral sprouting from spared cholinergic and noradrenergic afferents. Brain Res. 268: 27-37.

Goffinet, A. M., and V. S. Caviness (1986) Autoradiographic localization of $\beta_{1}$ - and $\alpha_{1}$-adrenoceptors in the midbrain and forebrain of normal and reeler mutant mice. Brain Res. 366: 193-202.

Grant, L. D., and L. E. Jarrard (1968) Functional dissociation within hippocampus. Brain Res. 10: 392-401.

Gray, R., and D. Johnston (1987) Noradrenaline and $\beta$-adrenoceptor agonists increase activity of voltage-dependent calcium channels in hippocampal neurons. Nature 327: 620-622.

Haas, H. L., and G. M. Rose (1987) Noradrenaline blocks potassium conductance in rat dentate granule cells in vitro. Neurosci. Lett. 78: 171-174.

Haring, J. H., and J. N. Davis (1983) Topography of locus coeruleus neurons projecting to the area dentata. Exp. Neurol. 79: 785-800.

Ilaring, J. H., and J. N. Davis (1985) Differential distribution of locus coeruleus projections to the hippocampal formation: Anatomical and biochemical evidence. Brain Res. 325: 366-369.

Herrling, P. L. (1981) The membrane potential of cat hippocampal neurons recorded in vivo displays four different reaction-mechanisms to iontophoretically applied transmitter agonists. Brain Res. 212: 331343.

Hjorth-Simonsen, A., and B. Jeune (1972) Origin and termination of the hippocampal perforant path in the rat studied by silver impregnation. J. Comp. Neurol. 144: 215-232.

Hoff, S. F., S. W. Scheff, L. S. Benardo, and C. W. Cotman (1982) Lesion-induced synaptogenesis in the dentate gyrus of aged rats: $I$. Loss and reacquisition of normal synaptic density. J. Comp. Neurol. 205: 246-252.

IIökfelt, T., O. Johansson, K. Fuxc, M. Goldstein, and D. Park (1976) Immunohistochemical studies on the localization and distribution of monoamine neuron systems in the rat brain. III. Three catecholamine synthesizing enzymes in the rhinencephalon. Symposium Bel-Air (Geneva): $79-113$.

Hopkins, W. F., and D. Johnston (1988) Noradrenergic enhancement of long-term potentiation at mossy fiber synapses in the hippocampus. J. Neurophysiol. 59: 667-687.

Jones, B. E., and R. Y. Moore (1977) Ascending projections of the locus coeruleus in the rat. II. Autoradiographic study. Brain Res. 127: 23-53.

Jones, L. S., L. L. Gauger, and J. N. Davis (1985) Anatomy of brain alpha ${ }_{1}$-adrenergic receptors; In vitro autoradiography with [ $\left.{ }^{125} 1\right] \mathrm{HEAT}$. J. Comp. Neurol. 231: 190-208.

Lacaillc, J.-C., and P. A. Schwartzkroin (1988a) Stratum lacunosummoleculare interneurons of hippocampal CA1 region. I. Intracellular response characteristics, synaptic responses, and morphology. J. Neurosci. 8: 1400-1410.

Lacaille, J.-C., and P. A. Schwartzkroin (1988b) Stratum lacunosum- moleculare interneurons of hippocampal CA1 region. II. Intrasomatic and intradendritic recordings of local circuit synaptic interactions. $J$. Neurosci. 8: 1411-1424.

Lacaille, J.-C., and P. A. Schwartzkroin (1988c) Intracellular responses of rat hippocampal granule cells to discrete applications of norepinephrine in vitro. Neurosci. Lett. 89: 176-181.

Lancaster, B., and P. R. Adams (1986) Calcium-dependent current generating the afterhyperpolarization of hippocampal neurons. J. Neurophysiol. 55: 1268-1282.

Langmoen, I. A., M. Segal, and P. Andersen (1981) Mechanisms of norepinephrine actions on hippocampal pyramidal cells in vitro. Brain Res. 208: 349-362.

Lapierre, Y., A. Beaudet, N. Demianczuk, and L. Descarries (1973) Noradrenergic axon terminals in the cerebral cortex of rat. II. Quantitative data revealed by light and electron microscope radioautography of the frontal cortex. Brain Res. 63: 175-182.

Lindvall, O., and A. Björklund (1974) The glyoxylic acid fluorescence histochemical method: A detailed account of the methodology for the visualization of central catecholamine neurons. Histochemistry 39 : 97-127.

Lorton, D., and J. N. Davis (1987) The distribution of beta-1 and beta-2 adrenergic receptors of normal and reeler mouse brain: An in vitro autoradiographic study. Neuroscience 23: 199-210.

Loy, R., D. A. Koziell, J. D. Lindsey, and R. Y. Moore (1980) Noradrenergic innervation of the adult hippocampal formation. J. Comp. Neurol. 189: 699-710.

Madison, D. V., and R. A. Nicoll (1982) Noradrenaline blocks accommodation of pyramidal cell discharge in the hippocampus. Nature 299: 636-638.

Madison, D. V., and R. A. Nicoll (1986a) Actions of noradrenaline recorded intracellularly in rat hippocampal CA1 pyramidal neurones in vitro. J. Physiol. (Lond.) 372: 221-244.

Madison, D. V., and R. A. Nicoll (1986b) Cyclic adenosine 3',5'monophosphate mediates $\beta$-receptor actions of noradrenaline in rat hippocampal pyramidal cells. J. Physiol. (Lond.) 372: 245-259.

Madison, D. V., and R. A. Nicoll (1988) Norepinephrine decreases synaptic inhibition in the rat hippocampus. Brain Res. 442: 131-138.

Milner, T., and C. E. Bacon (1989) Ultrastructural localization of tyrosine hydroxylase-like immunoreactivity in the rat hippocampal formation. J. Comp. Neurol. 281:479-495.

Moore, R. Y. (1975) Monoamine neurons innervating the hippocampal formation and septum: Organization and response to injury. In The Hippocampus, Vol. 1: Structure and Development, R. L. Isaacson and K. H. Pribram, eds., pp. 215-237, Plenum, New York.

Nagai, T., K. Satoh, K. Imamoto, and T. Maeda (1981) Divergent projections of catecholamine neurons of the locus coeruleus as revealed by fluorescent retrograde double labeling technique. Neurosci. Lett. 23: 117-123.

Neuman, R. S., and C. W. Harley (1983) Long-lasting potentiation of the dentate gyrus population spike by norepinephrine. Brain Res. 273: $162-165$.

Pang, K., and G. M. Rose (1987) Differential effects of norepinephrine on hippocampal complex-spike and theta-neurons. Brain Res. 425: 146-158.

Peterson, G. M. (1988) Sprouting of central and peripheral noradrenergic fibers into the dentate gyrus following combined lesions of the entorhinal and septal afferents. Soc. Neurosci. Abstr. 14: 890.

Rainbow, T. C., B. Parsons, and B. B. Wolfe (1984) Quantitative autoradiography of $\beta_{1}$ - and $\beta_{2}$-adrenergic receptors in rat brain. Proc. Natl. Acad. Sci. USA 81: 1585-1589.

Reader, T. A., and L. Grondin (1987) Distribution of catecholamines, serotonin, and their major metabolites in the rat cingulate, piriformentorhinal, somatosensory and visual cortex: A biochemical survey using high-performance liquid chromatography. Neurochem. Res. 12: 1087-1097.

Room, P., F. Postema, and J. Korf (1981) Divergent axon collaterals of rat locus coeruleus: Demonstration by fluorescent double labeling technique. Brain Res. 221: 219-230.

Sah, P., C. R. French, and P. W. Gage (1985) Effects of noradrenaline on some potassium currents in CA1 neurones in rat hippocampal slices. Neurosci. Lett. 60: 295-300.

Saper, C. B. (1987) Function of the locus coeruleus. Trends Neurosci. 10: 343-344.

Scheff, S. W., K. J. Anderson, and S. T. DeKosky (1985) Strain com- 
parison of synaptic density in hippocampal CAl of aged rats. Neurobiol. Aging 6: 29-34.

Segal, M. (1981) The action of norepinephrine in rat hippocampus: Intracellular studies in the slice preparation. Brain Res. 206: 107128

Sorensen, K. E., and M. T. Shipley (1979) Projections from the subiculum to the deep layers of the ipsilateral presubiculum and entorhinal cortices in the guinea pig. J. Comp. Neurol. 188: 313-334.

Stanton, P. K., and J. M. Sarvey (1985) Blockade of norepinephrineinduced long-lasting potentiation in the hippocampal dentate gyrus by an inhibitor of protein synthesis. Brain Res. 361: 276-283.

St. Laurent, J., M. F. Roizen, E. Miliaressis, and D. M. Jocobowitz (1975) The effects of self-stimulation on the catecholamine concentration of discrete areas of the rat brain. Brain Res. 99: 194-200.

Storm-Mathisen, J., and H. C. Guldberg (1974) 5-Hydroxytryptamine and noradrenaline in the hippocampal region: Effect of transection of afferent pathways on endogenous levels, high affinity uptake, and some transmitter-related enzymes. J. Neurochem. 22: 793-803.

Swanson, L. W., and W. M. Cowan (1977) An autoradiographic study of the organization of the efferent connections of the hippocampal formation in the rat. J. Comp. Neurol. 172: 49-84.

Swanson, L. W., and B. K. Hartman (1975) The central adrenergic system. An immunofluorescence study of the location of cell bodies and their efferent connections in the rat utilizing dopamine- $\beta$-hydroxylase as a marker. J. Comp. Neurol. 163: 467-506.

Tayrien, M. W., and R. Loy (1984) Computer-assisted image analysis to quantify regional and specific receptor ligand binding: Upregulation of $\left[{ }^{3} \mathrm{H}\right] \mathrm{QNB}$ and $\left[{ }^{3} \mathrm{H}\right]$ WB401 binding in denervated hippocampus. Brain Res. Bull. 13: 743-750.
Unnerstall, J. R., T. A. Kopajtic, and M. J. Kuhar (1984) Distribution of $\alpha_{2}$ agonist binding sites in the rat and human central nervous system: Analysis of some functional, anatomic correlates of the pharmacologic effects of clonidine and related adrenergic agents. Brain Res. Rev. 7: 69-101.

Verney, C., M. Baulac, B. Berger, C. Alvarez, A. Vigny, and K. B. Helle (1985) Morphological evidence for a dopaminergic terminal field in the hippocampal formation of young and adult rat. Neuroscience 14 : 1039-1052.

Versteeg, D. H. G., J. Van Der Gugten, W. De Jong, and M. Palkovits (1976) Regional concentrations of noradrenaline and dopamine in rat brain. Brain Res. 113: 563-574.

West, M. J., W. Danscher, and H. Gydesen (1978) A determination of the volumes of the layers of the rat hippocampal region. Cell Tissue Res. 188: 345-359.

West, M. J., P. D. Coleman, and D. G. Flood (1988) Estimating the number of granule cells in the dentate gyrus with the disector. Brain Res. 448: 167-172.

Winson, J., and D. Dahl (1985) Action of norepinephrine in the dentate gyrus. II. Iontophoretic studies. Exp. Brain Res. 59: 497-506.

Young, W. S., and M. J. Kuhar (1980) Noradrenergic $\alpha_{1}$ and $\alpha_{2}$ receptors: Light microscopic autoradiographic localization. Proc. Natl. Acad. Sci. USA 77: 1696-1700. 